\title{
Serum levels of lysozyme in term and preterm newborns
}

\author{
M. XANTHOU, A. AGATHOPOULOS, A. SAKELLARIOU, C. ECONOMOU-MAVROU, \\ S. TSINGOGLOU, and N. MATSANIOTIS \\ From 1st Department of Paediatrics, Athens University, Greece
}

\begin{abstract}
Xanthou, M., Agathopoulos, A., Sakellariou, A., Economou-Mavrou, C., Tsingoglou, S., and Matsaniotis, N. (1975). Archives of Disease in Childhood, 50, 304. Serum levels of lysozyme in term and preterm newborns. Serum lysozyme levels were studied in term babies at the time of delivery and again between the 7th and 30th postnatal days, and in preterm babies on the 1st, 3rd, and 5th postnatal days. Levels in term babies at delivery (mean $2.28 \mu \mathrm{g} / \mathrm{ml}$ ) were similar to those found in adults, but they fell between the 7th and 30th postnatal days.

In preterm babies lysozyme levels on the first day of life (mean $(0.82 \mu \mathrm{g} / \mathrm{ml}$ ) were lower than in term babies. They tended to rise during the first 5 days, by which time they had reached levels found in term babies between the 7th and 30th days.

The low lysozyme levels in preterm and in term babies after the first few days of life may contribute to the poor ability of the newborn baby to localize infection and to kill bacteria extracellularly.
\end{abstract}

Since 1922 when Fleming reported the discovery of a 'remarkable bacteriolytic element found in tissues and secretions', lysozyme (muramidase) has been studied extensively both in health (Hansen, Karle, and Andersen, 1969; Barratt and Crawford, 1970; Hansen et al., 1972; Wright and Malawista, 1972; Hansen and Andersen, 1973) and disease (Catovsky et al., 1971; Perillie et al., 1968; Weissmann, 1967; Osserman and Lawlor, 1966; Perin and Jollés, 1972; Hansen, 1973; Jensen, 1973). After the discovery that plasma lysozyme is mainly derived from disintegrating neutrophilic granulocytes (Hansen et al., 1969; Fink and Finch, 1968) this enzyme was also used in the study of leucokinetics (Hansen et al., 1969; Catovsky et al., 1971; Hansen, 1973).

It is recognized that lysozyme acts against a wide variety of Gram-positive bacteria (Gajdos, 1971). Apparently it also acts in vivo synergistically with other enzymes or agents against many other bacteria which are resistant to the enzyme in vitro (Salton, 1957; Carson and Dannenberg, 1965; Miller, 1969).

Little is known about lysozyme in the newborn, whose poor resistance to infection is imperfectly understood. This study reports lysozyme levels in the plasma of newborns, both term and preterm.

Received 7 October 1974.

\section{Material and methods}

Plasma lysozyme levels were studied in three groups. (a) 20 term newborns at the time of delivery, and 18 at some time between the 7th and 30th days of life. (b) 13 preterm babies on the 1st, 3rd, and 5th days of life. 6 had a gestational age of 30-33 weeks and 6 of 33-36 weeks. One was also small-for-dates (gestational age 34 weeks). (c) 16 adults, aged 20-30 years. All were healthy at the time of the study, but most of the preterm babies were receiving prophylactic antibiotic therapy, either because of prolonged rupture of membranes or because of poor transportation conditions.

The blood specimens were obtained either by venepuncture or from a free-flowing heel prick. EDTA was used as anticoagulant. Serum lysozyme was estimated by the turbidimetric method of Parry, Chandan, and Shahani (1965). A suspension of Micrococcus lysodeikticus (Sigma) was used as substrate, and egg-white lysozyme (Sigma) as standard. Changes in optical density were measured in a Zeiss spectrophotometer. Normal sera were tested at a dilution of 1 in 5 in order to obtain a linear rate of clearance of the suspension. The error of the method was up to $10 \%$.

\section{Results}

The mean plasma lysozyme concentration in adults was $2 \cdot 19 \mu \mathrm{g} / \mathrm{ml}$ (range $0 \cdot 30-4 \cdot 20 \mu \mathrm{g} / \mathrm{ml}$ ). A similarly wide range was observed in term babies at the time of delivery, but the mean 
value tended to be slightly higher than in adults $(2 \cdot 38 \mu \mathrm{g} / \mathrm{ml})$, though not significantly so $(P>0.05)$. In preterm babies during the first day of life lysozyme levels were considerably lower than in term babies $(P<0.001)$. The mean value being $0.82 \mu \mathrm{g} / \mathrm{ml}$ and the range narrower (Fig. 1). There was no difference in plasma lysozyme between preterm babies born at 30-33 weeks of gestation and those born at 33-36 weeks. The one small-for-dates preterm baby had a value of $0.59 \mu \mathrm{g} / \mathrm{ml}$.

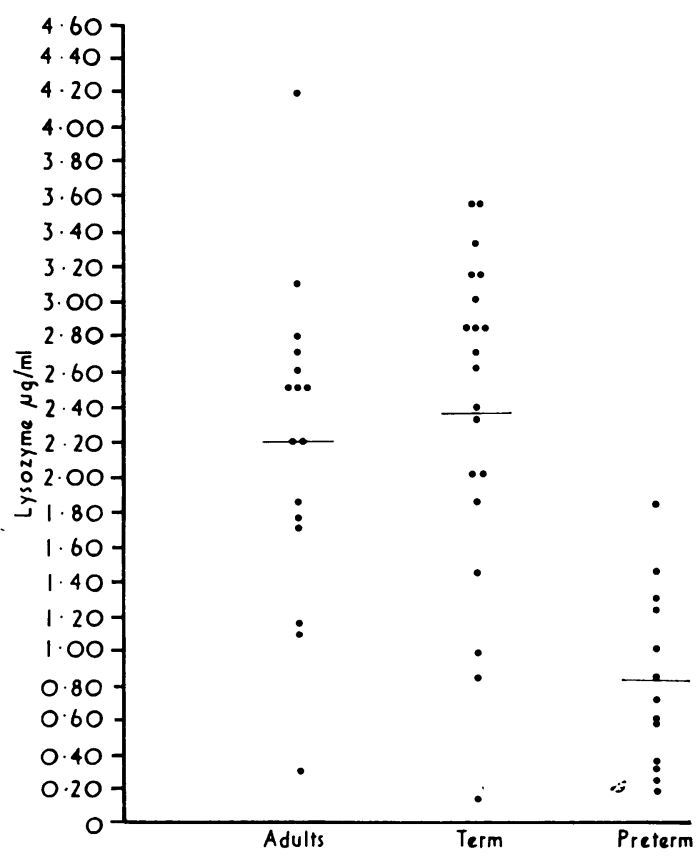

FIG. 1.-Lysozyme levels in adults, and term and preterm babies on the first day of life.

Plasma lysozyme levels in the 18 term babies at age 7 to 30 days were much lower than in the 20 term babies at delivery (mean $1.01 \mu \mathrm{g} / \mathrm{ml}$ against $2 \cdot 28 \mu \mathrm{g} / \mathrm{ml})(P<0 \cdot 001)$ (Fig. 2).

Lysozyme levels in preterm babies tended to rise during the first 5 postnatal days (Fig. 3) though this rise did not reach statistical significance. By the end of the first week of life plasma lysozyme levels were similar in term and preterm babies.

\section{Discussion}

Plasma lysozyme levels in our term babies at delivery were about the same as in adults. Other workers have reported values of term babies

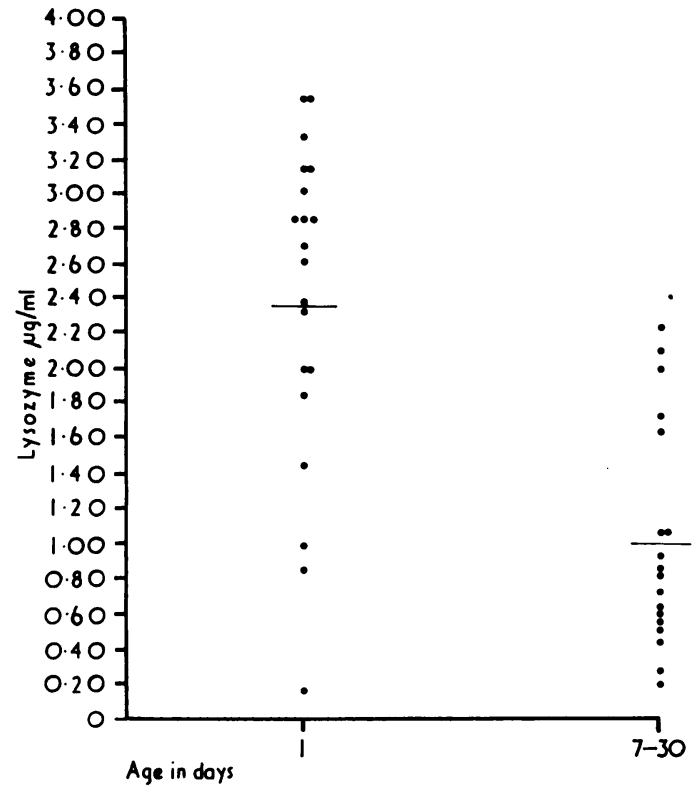

FIG. 2.-Lysozyme levels in term babies on the 1st day and between the 7th and 30th days of life.

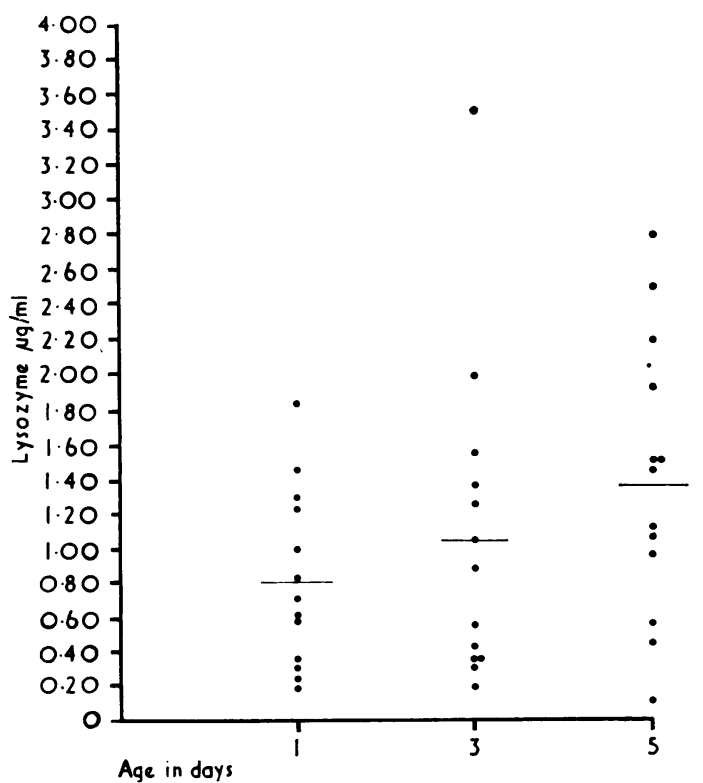

FIG. 3.-Lysozyme levels in preterm babies on the 1st, $3 r d$, and 5 th days of life.

during the first days of life as either similar (Barratt and Crawford, 1970) or higher than in adults (Glynn, Martin and Adinolfi, 1970; IwaszkoKrawczuk and Merkiel, 1973). 
The fall of plasma lysozyme in term babies after the first week of life has not been previously reported. What is the cause of this fall? It could be postulated that plasma lysozyme in the term newborn at delivery reflects that of the maternal plasma, for lysozyme is a small molecular weight protein (15.000, Gajdos, 1971) which might easily cross the placenta. Rapid catabolism (Hansen et al., 1972) and/or deficient synthesis by the neonate might then be responsible for the subsequent fall in level. However, Glynn et al. (1970) found no correlation between the concentration of lysozyme in maternal and neonatal sera at delivery, suggesting that lysozyme is produced by the fetus. If this be true, and if the enzyme does not cross the placenta, the fall after the first week of life could result from loss via the relatively immature neonatal kidney (Hansen et al., 1972). Alternatively, the ability of the newborn to synthesize lysozyme may be inadequate to compensate for increased demands after birth.

Barratt and Crawford (1970) found no difference in the renal excretion of lysozyme between healthy adults and term neonates. Hence, the most plausible explanation for the fall in plasma lysozyme after the first postnatal week is inadequate synthesis. Studies of the lysozyme content of neonatal polymorphonuclear neutrophils of the peripheral blood would further elucidate the problem and such work is now under way.

In preterm babies lysozyme levels during the 1st day of life were lower than in term babies at delivery. No previous work has come to our notice regarding lysozyme levels in preterm babies. In term, small-for-dates babies, lysozyme levels were lower than in term babies of normal weight (Iwasko-Krawczuk, 1973).

Lysozyme has been found to be present in fetal serum as early as the 9th-12th week of gestation and low values have been reported in fetuses of about 16 weeks (Glynn et al., 1970). It seems that lysozyme levels only reach adult levels towards the end of gestation.

It is interesting that in contrast to what happens in term newborns, plasma lysozyme in preterm babies tends to rise during the first 5 days of life. At birth plasma lysozyme in prematures is in the process of rising, and apparently it continues to do so after birth, though probably not at the same rate as before birth. By the 5th postnatal day lysozyme levels in preterm babies have reached those attained by term babies after the 7th day of life.

It is improbable that all these changes in plasma lysozyme are to be ascribed to differences in the granulocyte turnover (Hansen, 1973) between term and preterm babies, because granulocyte changes in the peripheral blood during the first days of life are very similar in both (Xanthou, 1970).

We suggest that the initially lower plasma lysozyme levels in preterm babies may be one reason why they are vulnerable to infections during the first few days of life. The lower values found in both term and preterm babies after the first few days of life may have some relation to the newborn infant's ability to combat infection, and to kill bacteria extracellularly.

\section{REFERENCES}

Barratt, T. M., and Crawford, R. (1970). Lysozyme excretion as a measure of renal tubular dysfunction in children. Clinical Science, 39, 457.

Carson, M. E., and Dannenberg, A. M. Jr. (1965). Hydrolytic enzymes of rabbit mononuclear exudate cells. II. Lysozyme. Properties and quantitative assay in tuberculous and control inbred rabbits. Fournal of Immunology. 94, 99.

Catovsky, D., Galton, D. A. G., Griffin, C., Hoffbrand, A. V., and Szur, L. (1971). Serum lysozyme and vitamin $B_{12}$ binding capacity in myeloproliferative disorder. British fournal of Haematology, 21, 661 .

Fink, M. E., and Finch, S. C. (1968). Serum muramidase and granulocyte turnover. Proceedings of the Society for Experimental Biology and Medicine, 127, 365.

Fleming, A. (1922). On a remarkable bacteriolytic element found in tissues and secretions. Proceedings of the Royal Society. Series $B, 93,306$.

Gajdos, A. (1971). Biochimie des lysozymes. Presse Medicale, 79, 351.

Glynn, A. A., Martin, W., and Adinolfi, M. (1970). Levels of lysozyme in human foetuses and newborns. Nature, 225, 77.

Hansen, N. E. (1973). The relationship between the turnover rate of neutrophilic granulocytes and plasma lysozyme levels. British fournal of Haematology, 25, 771.

Hansen, N. E., and Anderson, V. (1973). Lysozyme activity in human neutrophilic granulocytes. British fournal of Haematology, 24, 613.

Hansen, N. E., Karle, H., and Andersen, V. (1969). Muramidase activity of bone marrow plasma. Acta Medica Scandinavica, 185, 387.

Hansen, N. E., Karle, H., Andersen, V., and Ølgaard, K. (1972). Lysozyme turnover in man. Fournal of Clinical Investigation, $51,1146$.

Jensen, H. (1973). Renal handling of muramidase in patients with kidney diseases or hypertension. Scandinavian fournal of Clinical and Laboratory Investigation, 32, 111.

Iwaszko-Krawczuk, W. (1973). Serum lysozyme activity in the small-for-dates newborn. Acta Paediactrica Academiae Scientiarum Hungaricae, 14, 135.

Iwaszko-Krawczuk, W., and Merkiel, K. (1973). The lysozyme activity in blood serum samples from term newborns. Ginekologia Polska, 44, 588.

Miller, T. E. (1969). Killing and lysis of gram-negative bacteria through the synergistic effect of hydrogen peroxide, ascorbic acid, and lysosyme. Fournal of Bacteriology, 88, 949.

Osserman, E. F., and Lawlor, D. P. (1966). Serum and urinary lysozyme (muramidase) in monocytic and monomyelocytic leukemia. Fournal of Experimental Medicine, 124, 921.

Parry, R. M. Jnr., Chandan, R. C., and Shahani, K. M. (1965). A rapid and sensitive assay of muramidase. Proceedings of the Society for Experimental Biology and Medicine, 119, 384.

Perillie, P. E., Kaplan, S. S., Lefkowitz, E., Rogaway, W., and Finch, S. C. (1968). Studies of muramidase (lysozyme) in leukemia. Fournal of the American Medical Association, 203, 317.

Perin, J. P., and Jollés, P. (1972). Etude comparte des lysozymes de leucocytes de sujets sains et de malades atteints de leucemie myéloide chronique. Clinica Chimica Acta, 42, 77. 
Salton, M. R. J. (1957). The properties of lysozyme and its action on microorganisms. Bacteriological Reviews, 21, 82.

Weissmann, G. (1967). The role of lysosomes in inflammation and disease. Annual Review of Medicine, 18, 97.

Wright, D. G., and Malawista, S. E. (1972). The mobilization and extracellular release of granular enzymes from human leukocytes during phagocytosis. Fournal of Cell Biology, 53, 788.
Xanthou, M. (1970). Leucocyte blood picture in healthy fullterm and premature babies during neonatal period. Archives of Disease in Childhood, 45, 242.

Correspondence to Dr. M. Xanthou, 1st Department of Paediatrics, Athens University, 'Aghia Sophia' Children's Hospital, Athens 608, Greece. 